\title{
CALCULATION OF SULPHUR AND NITROGEN DEPOSITION WITH THE FRAME MODEL AND ASSESSMENT OF THE EXCEEDANCE OF CRITICAL LOADS IN POLAND
}

\author{
MODELOWANIE DEPOZYCJI ZWIĄZKÓW SIARKI I AZOTU \\ ORAZ ANALIZA PRZEKROCZEŃ LADUNKÓW KRYTYCZNYCH W POLSCE
}

\begin{abstract}
Sulphur and nitrogen deposition were calculated with the FRAME model and used to assess the exceedances of the critical loads for acidification and eutrophication of natural ecosystems in Poland. For the first time two tools: the FRAME and SONOX models were used jointly to provide information on ecosystems at risk. The FRAME model obtained close agreement with available sulphur and nitrogen wet deposition measurements. The total mass of sulphur deposited in Poland in year 2008 was estimated as $292 \mathrm{Gg}$ S. Total deposition of nitrogen (oxidized + reduced) is $389 \mathrm{Gg} \mathrm{N} .11 \%$ of the ecosystems in Poland were calculated to be at risk of acidification due to deposition of sulphur and nitrogen. In the case of eutrophication, over $95 \%$ of terrestrial ecosystems are at risk due to the large deposition of nitrogen compounds.
\end{abstract}

Keywords: sulphur deposition, nitrogen deposition, critical loads, acidification, eutrophication

\section{Introduction}

Emission of sulphur (S) and nitrogen $(\mathrm{N})$ to the atmosphere in Poland has been reduced significantly over the last two decades as a result of economical changes and the successful application of emissions abatement policies [1]. However, Poland is still among the European countries with the largest emissions of atmospheric pollutants. This, together with transboundary transport of pollutants, leads to the elevated deposition of sulphur and nitrogen compounds. Deposition of S and $\mathrm{N}$ may result in the exceedances of critical loads (CL) for acidification and eutrophication of aquatic and terrestrial ecosystems. Further consequences include extinction of species and decrease in biodiversity [2, 3]. Recent studies carried out under the revision of the Gothenburg Protocol of the Convention on Long Range Transboundary Air Pollution suggest that the nutrient critical loads are

\footnotetext{
${ }^{1}$ Department of Climatology and Atmosphere Protection, Wrocław University, ul. Kosiby 8, 51-621 Wrocław, Poland, phone +48 713485441

${ }^{2}$ Institute of Environmental Protection, KASHUE-KOBIZE, Poland

${ }^{3}$ Centre for Ecology and Hydrology, Edinburgh, UK

*Corresponding author: maciej.kryza@uni.wroc.pl
} 
exceeded for almost the entire area of natural ecosystems of Poland. The prognosis for the years 2020 and 2030 suggest only small improvements [4]. The percentage of ecosystem areas at risk of eutrophication was ca. $100 \%$ for year 2000, and is expected to decrease to $98 \%$ in 2020 and $97 \%$ in 2030 [4]. Similar situation is also expected for the majority of the European countries. The respective numbers for acidification are $77 \%$ for year 2000, decreasing to 35 and $33 \%$ in years 2020 and 2030. Netherlands is the only European country with the higher percentage of ecosystem areas at risk of acidification in the year 2030 than in Poland (66\%) [4].

To assess the CL exceedances, atmospheric transport models are usually applied to provide spatial information on $\mathrm{S}$ and $\mathrm{N}$ deposition to the ecosystems. At the national scale and due to the computational costs, these models are often applied with coarse spatial resolution which may lead to under or overestimation of ecosystem exposure [5]. Dore et al [6] examined the role of various model resolutions on the national scale statistics of exceedances of the critical load for nutrient nitrogen in the UK. He found that the spatial resolution of the modelled sulphur and nitrogen deposition can significantly affect the final information on eg habitat areas with the exceeded critical load for nutrient nitrogen deposition [6]. Also the changes in spatial distribution and the value of the exceedance level were significantly affected when $e g 1 \mathrm{~km} \times 1 \mathrm{~km}$ and $50 \mathrm{~km}$ x $50 \mathrm{~km}$ deposition data were used for the exceedances calculations.

In Poland, EMEP-Unified modelled sulphur and nitrogen deposition with $50 \mathrm{~km}$ x $50 \mathrm{~km}$ spatial resolution has been used so far to assess the risk of acidification and eutrophication in Poland with the SONOX model $[1,7,8]$. In this paper, the high resolution Fine Resolution Atmospheric Multi-pollutant Exchange (FRAME) model is used to study spatial patterns of dry, wet and total deposition of sulphur and nitrogen compounds in Poland in year 2008. For the first time $\mathrm{S}$ and $\mathrm{N}$ deposition, calculated with the FRAME model at a $5 \mathrm{~km} \times 5 \mathrm{~km}$ spatial resolution, are used as an input to the SONOX model for assessment of the exceedances of CLs for acid and nitrogen deposition (the excess of deposition load over the critical load) at national scale.

\section{Materials and methods}

\section{The FRAME model}

FRAME is a statistical Lagrangian trajectory atmospheric transport model that provides information on annual deposition and average concentrations of sulphur and nitrogen compounds, particulate matter $\left(\mathrm{PM}_{2.5}\right.$ and $\left.\mathrm{PM}_{10}\right)$, base cations and heavy metals for the United Kingdom, Poland and China. A detailed description of the model and its application for the United Kingdom, where the model is used to support decisions on control of pollutant emission, is provided by works [9-12]. The details of the model configuration for Poland are provided by Kryza et al [13, 14].

The FRAME model describes the main atmospheric processes in a column of air moving along straight-line trajectories. The trajectories are advected from the edge of the model domain at different starting angles with a $1^{\circ}$ resolution, using directionally dependant wind frequency and speed roses. Wind roses are derived using radiosonde measurements and the method described by Dore et al [10]. In this paper, the wind roses were calculated with data gathered at meteorological stations located within the model domain: Wroclaw, Warszawa (Warsaw), Leba, Greifswald, Lindenberg, Prague, Poprad and Kiev. 
The model column consists of 33 vertical layers of thickness varying from $1 \mathrm{~m}$ at the surface to $100 \mathrm{~m}$ at the top of the model domain $(2500 \mathrm{~m})$. Vertical diffusion of gases and aerosols is described with K-theory eddy diffusivity and solved with the Finite Volume Method. The vertical diffusivity $\left(K_{z}\right)$ has a linearly increasing value up to specified height $\left(H_{z}\right)$ and then remains constant $\left(K_{\max }\right)$ to the top of the boundary layer. During daytime, $H_{z}$ is taken as $200 \mathrm{~m}$ and $K_{\max }$ is a function of the boundary layer depth and the geostrophic wind speed. For night-time, these values depend on the Pasquil stability classes.

The chemistry scheme of the FRAME model is similar to the one used in the EMEP Lagrangian model [15]. The scheme includes photolytic dissociation of $\mathrm{NO}_{2}$, oxidation of $\mathrm{NO}$ by ozone, formation of $\mathrm{PAN}$ and $\mathrm{HNO}_{3}$ by reaction with the hydroxyl $(\mathrm{OH})$ free radical. Ammonium nitrate aerosol is formed by the equilibrium reaction between $\mathrm{HNO}_{3}$ and $\mathrm{NH}_{3}$. The formation of $\mathrm{H}_{2} \mathrm{SO}_{4}$ by gas-phase oxidation of $\mathrm{SO}_{2}$ is represented by a predefined oxidation rate, and $\mathrm{H}_{2} \mathrm{SO}_{4}$ reacts with $\mathrm{NH}_{3}$ to form ammonium sulfate aerosol. The aqueousphase reactions in the model include the oxidation of S(IV) by ozone, hydrogen peroxide and the metal-catalyzed reaction with oxygen.

Dry deposition is calculated by determining vegetation dependent velocities to each chemical species derived from the dry deposition model [16]. Wet deposition is calculated with scavenging coefficients and a constant drizzle approach, using precipitation rates calculated from a map of average annual precipitation. The wet deposition flux to the surface is the sum of wet removal from all volume elements aloft, assuming that the scavenged material comes down as precipitation. There is no difference between in-cloud and below-cloud processes and an averaged value of scavenging ratio $(\Delta i)$ is applied in the FRAME model. To produce the scavenging coefficient $\lambda i, \Delta i$ is combined with the precipitation rate and the depth of the mixing layer $\Delta H$ mix. A doubled washout rate is assumed over hill areas due to the seeder-feeder effect, which is in accordance with measurements of wet deposition made in the Sudete Mts. SW Poland [17].

In this paper, the model was applied to the area of Poland, with a domain of $160 \times 160$ grid cells of size $5 \mathrm{~km}$ x $5 \mathrm{~km}$. Boundary conditions were calculated with the FRAME-Europe model, that was run for the entire Europe with spatial resolution of $50 \mathrm{~km} \times 50 \mathrm{~km}$ on the EMEP grid using emissions from the EMEP database.

\section{Emission inventory}

The Polish national emission inventory for year 2008 was used in this study [18], and regridded onto the FRAME model mesh with the method presented by Kryza et al [13]. Emission data for the remaining areas of the model domain (neighbouring countries) were taken from the EMEP inventory [19]. Emission from point sources were provided by KASHUE/KOBIZE and EPRTR databases and included in the model together with information on stack height, diameter, temperature and velocity of the outflow gases. The data were used with a plume rise model to calculate effective emission height [11]. The total mass of sulphur emitted in Poland in year 2008 was $999 \mathrm{Gg}$ of $\mathrm{SO}_{2}$. For nitrogen, it was $831 \mathrm{Gg}$ of $\mathrm{NO}_{2}$, and $285 \mathrm{Gg}$ of $\mathrm{NH}_{3}$.

\section{Evaluation of the FRAME model results}

A twofold evaluation of the FRAME model results was undertaken in this study. In both cases, the focus was on sulphur and nitrogen deposition, as the results of the model were further used to assess the critical loads exceedances with the SONOX model. First, the 
FRAME modelled dry and wet national deposition budgets (total mass of S and N deposited in Poland) for year 2008 were calculated and compared with the EMEP model estimates and measurement-based estimates calculated by the Polish Chief Inspectorate of Environment Protection (CIEP). This approach was important because of the following reasons:

- $\quad$ EMEP is the model that is widely used to provide deposition data for the critical loads exceedances in European countries including Poland [4, 8].

- Direct dry deposition measurements of sulphur and nitrogen compounds were not available. A model to model comparison was therefore the only way to evaluate the results.

- The results of three models with different theoretical backgrounds were compared - the complex Eulerian EMEP-Unified model, driven by modelled dynamic meteorological information, the measurement-based approach of CIEP, and FRAME, a relatively simple statistical transport model driven by annually averaged meteorological data.

Apart from model to model comparison, wet deposition of $\mathrm{S}$ and $\mathrm{N}$ calculated with the FRAME model was compared with the wet deposition measurements gathered in the model domain for the year 2008. The measurements were collected at 37 sites equipped with the wet only samplers. The model error was calculated as the difference between the modelled $(M)$ and observed value $(O)$ for each station. The errors were summarized using the following statistics:

- $\quad$ mean bias (MB $[\mathrm{kg}]): \mathrm{MB}=\frac{1}{N} \sum_{i=1}^{N}\left(M_{i}-O_{i}\right)$

- normalized mean bias (NMB): $\mathrm{NMB}=\frac{\sum_{i=1}^{N}\left(M_{i}-O_{i}\right)}{\sum_{i=1}^{N} O_{i}}$

- mean absolute gross error (MAGE [kg]): MAGE $=\frac{1}{N} \sum_{i=1}^{N}\left|M_{i}-O_{i}\right|$

- fraction of two (FAC2, unit-less): FAC2 $=\frac{1}{N} \sum n_{i}$ where: $n_{i}=\left\{\begin{array}{l}1 \text { for } 0.5 \leq\left|\frac{M_{i}}{O_{i}}\right| \leq 2 \\ 0 \text { for all others }\end{array}\right.$

- Pearson correlation coefficient ( $R$, unit-less).

\section{Calculation of critical loads and their exceedances}

Depending on the effects generated by atmospheric deposition of sulphur and nitrogen two definitions of critical loads can be distinguished [20]:

- The critical load of acidity is the highest deposition of acidifying compounds as sulphur and oxidized and reduced nitrogen, that will not cause chemical changes leading to long-term harmful effects on ecosystem structure and function.

- The critical load for eutrophication is the highest deposition of nutrient nitrogen below which harmful eutrophying effects on ecosystem structure and function do not occur according to present knowledge. 
The purpose of a model-based approach to calculate critical loads is to link, via mathematical equations, a given chemical criterion (critical limit) with the maximum deposition "below which significant harmful effects on specified sensitive elements of the environment do not occur, ie for which the criterion is not violated" [20].

The CL model is based on the following mass balance equation - the so called Simple Mass Balance model (SMB) [21]:

$$
S_{d e p}+N_{d e p}=B C_{d e p}+B C_{w}-B c_{u}+N_{u}+N_{i}+N_{d e}-A N C_{l e}
$$

where: $S_{d e p}$ - sulphur deposition, $N_{d e p}$ - total nitrogen deposition, $B C_{d e p}$ - base cation deposition rate, $B C=\mathrm{Ca}+\mathrm{Mg}+\mathrm{K}+\mathrm{Na}, B C_{w}$ - base cation weathering rate, $B c_{u}$ - base cation uptake rate, $B c=\mathrm{Ca}+\mathrm{Mg}+\mathrm{K}, N_{u}$ - net removal of nitrogen in harvested vegetation, $N_{i}$ - long-term net immobilization of nitrogen in soil organic matter, $N_{d e}$ - flux of nitrogen to the atmosphere due to soil denitrification, $A N C_{l e}$ - leaching of acid neutralizing capacity. All quantities are given in eq $\mathrm{ha}^{-1}$ year $^{-1}$.

\section{Critical loads of acidity}

By defining a critical ANC leaching $A N C_{\text {le(crit) }}$ in the above equation critical loads of sulphur $C L(S)$ and nitrogen $C L(N)$ can be computed. Because sulphur and nitrogen simultaneously contribute to acidification and nitrogen sinks cannot compensate for incoming sulphur acidity due to partial consumption by immobilization and denitrification, a function of critical loads of acidity must be considered of the shape presented in Figure 1.

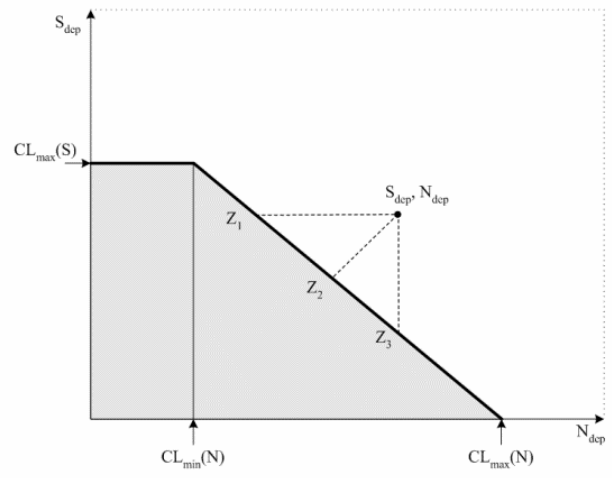

Fig. 1. The function of critical loads for acid deposition

This function is defined by the three quantities:

$C L_{\text {max }} S$ - maximum critical load of sulphur, which is the maximum tolerable sulphur deposition in case of zero deposition of nitrogen:

$$
C L_{\max } S=B C_{d e p}+B C_{w}-B c_{u}-A N C_{\text {le(crit })}
$$

$C L_{\min } N$ - minimum critical load of nitrogen, which equals to long-term net removal and immobilization of nitrogen in soil:

$$
C L_{\min } N=N_{i}+N_{u}+N_{d e}
$$


$C L_{\max } N$ - maximum critical load of nitrogen is the harmless maximum deposition of nitrogen in case of zero sulphur deposition:

$$
C L_{\max } N=C L_{\min } N+\frac{C L_{\max } S}{1-f_{d e}}
$$

where $f_{d e}$ is the denitrification fraction, a site-specific quantity. The exceedance of the critical load can be achieved by reduction of nitrogen deposition only $\left(Z_{1}\right.$ on Fig. 1$)$, sulphur deposition only $\left(Z_{3}\right)$ and sulphur and nitrogen deposition $\left(Z_{2}\right)$.

\section{Critical loads of eutrophication}

The point of departure to derive critical loads of eutrophication is the following mass balance equation:

$$
N_{d e}=f_{d e} \cdot\left(N_{d e p}-N_{i}-N_{u}\right) \text { for } N_{d e p}>N_{i}+N_{u}
$$

From this equation a critical load is obtained by defining an acceptable limit to the leaching of nitrogen $N_{l e(c r i t)}$. Inserting this critical leaching to the above equation, the deposition of nitrogen becomes the critical load of nutrient nitrogen also called eutrophication:

$$
C L_{n u t}(N)=N_{i}+N_{u}+\frac{N_{l e(c r i t)}}{\left(1-f_{d e}\right)}
$$

\section{Critical load exceedances}

In general exceedance of a critical load of acidity or nutrient nitrogen is the excess of actual acid and/or nitrogen deposition over their critical values for a given ecosystem. In terms of ecosystem protection exceedance of critical load is a quantitative measure of the potential risk to functioning and structure of an ecosystem.

In case of exceedances of critical loads of acidity the calculating procedure is relatively complex due to the possible combinations of simultaneously acting sulphur and nitrogen depositions. To calculate exceedances of critical loads of eutrophication it simply needs to subtract their values from actual nitrogen atmospheric deposition.

\section{Results}

The results are organized as follows - first, the FRAME model evaluation results are presented, to give insight on the quality of the FRAME calculated deposition values and the agreement with the EMEP and CIEP sulphur and nitrogen national deposition budgets estimates. Then FRAME model derived spatial patterns of total (wet + dry) $\mathrm{S}$ and $\mathrm{N}$ depositions are presented. Finally the maps of CL of acidification and eutrophication and CL exceedances are provided.

FRAME modelled wet deposition is in good correlation with available measurements, especially for nitrogen compounds (Fig. 2, Table 1). There is one measuring site with overestimated wet deposition of sulphur and nitrogen - Kasprowy Wierch (Tatra Mts.), located at the mountain top (1987 $\mathrm{m}$ a.s.1.). The good agreement with the measurements shows that the model works correctly for Poland and can be applied to assess the critical loads exceedances of acidity and eutrophication. There is a small tendency for 
overestimation of measured wet deposition by the model for oxidized sulphur and nitrogen, reflected in positive MB and NMB. For reduced nitrogen, wet deposition is underestimated. The model is found to satisfy the criteria of being 'fit for purpose' that over $50 \%$ of modelled data points should be within 0.5 times and 2 times the measured value, which is described by the FAC2 statistics (Table 1).
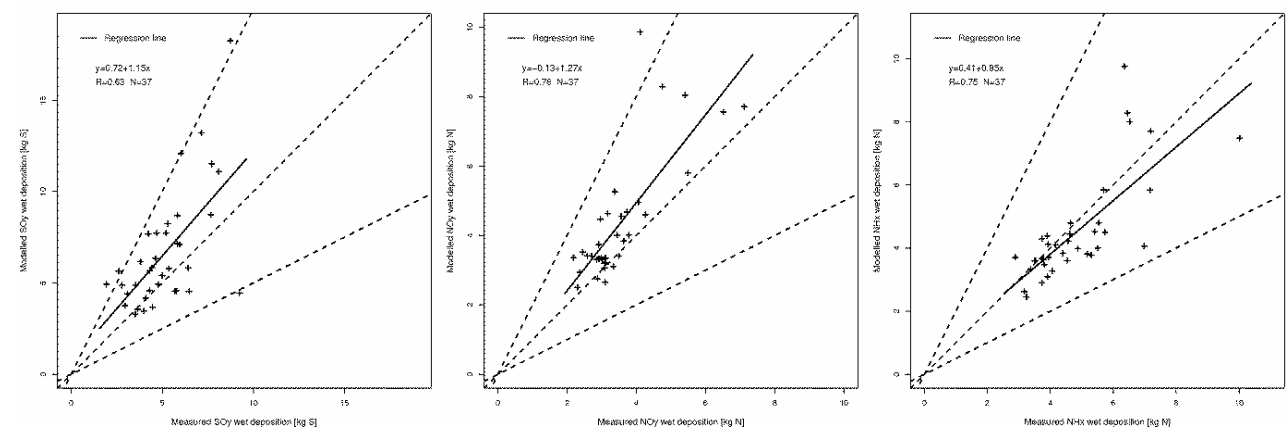

Fig. 2. Modelled vs measured wet deposition of oxidised sulphur, nitrogen and reduced nitrogen

Table 1

Error statistics for wet deposition of oxidized sulphur and nitrogen compounds

\begin{tabular}{|c|c|c|c|}
\hline & $\mathbf{S O}_{\mathbf{x}}$ & $\mathbf{N O}_{\mathbf{y}}$ & $\mathbf{N H}_{\mathbf{x}}$ \\
\hline MB & 1.49 & 0.81 & -0.32 \\
\hline NMB & 0.29 & 0.23 & -0.06 \\
\hline MAGE & 2.11 & 0.86 & 0.85 \\
\hline FAC2 & 0.86 & 0.97 & 1.00 \\
\hline
\end{tabular}

The total mass of oxidized sulphur deposited in Poland in year 2008 calculated with FRAME is $292 \mathrm{Gg}$ S. For oxidized nitrogen, it is $188 \mathrm{Gg} \mathrm{N}$ and for reduced nitrogen $201 \mathrm{Gg} \mathrm{N}$. In the case of oxidized sulphur and nitrogen ca. $60 \%$ of national deposition budget is wet deposited with precipitation (Fig. 3). For reduced nitrogen, wet deposition contributes over $64 \%$ with the remainder coming from dry deposition.

The FRAME model estimates of the dry and wet deposition budgets are in reasonable agreement with the EMEP-Unified models (Fig. 3). The differences are specially large for dry deposition of oxidised sulphur and nitrogen, with FRAME providing higher values. Both models show good agreement for dry deposition of reduced nitrogen (difference is $5 \%$ ). For the national deposition budget of wet deposition, the FRAME model estimates are higher than EMEP for all chemical species considered, with the largest differences for oxidised nitrogen (15\%). The EMEP calculated wet deposition budgets are below the CIEP estimates for sulphur and nitrogen compounds. For FRAME, only the wet deposition budget for oxidised nitrogen is higher than calculated by CIEP. The FRAME values are closer to the measurement-based CIEP depositions than the EMEP estimates, with the largest discrepancies found for reduced nitrogen (16\% difference for FRAME vs CIEP and 22\% for EMEP vs CIEP). It should be noticed however that the CIEP approach, which is based on wet deposition and precipitation measurements, suffers from the low network density especially over the mountain area in the south of Poland. 

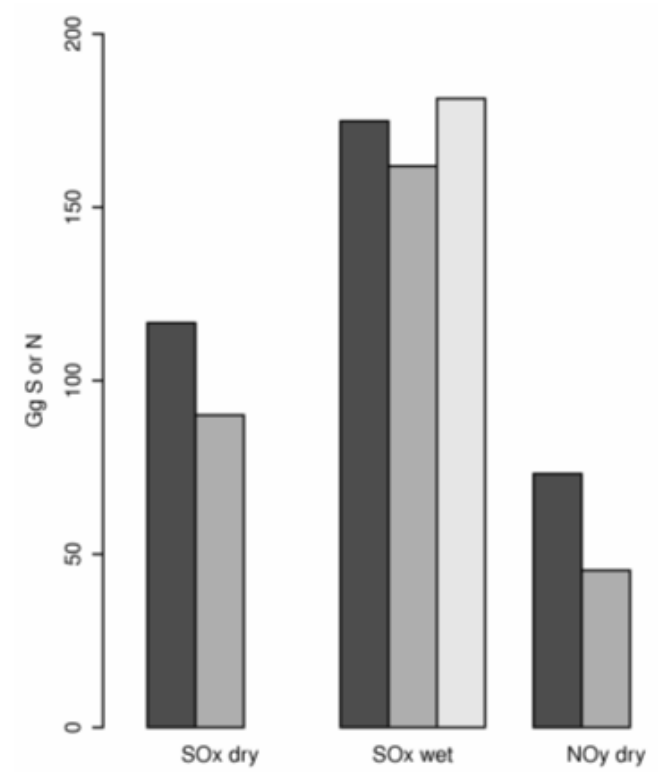

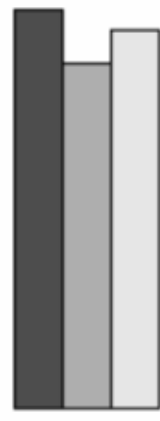

NOy wet

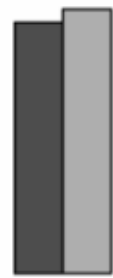

NHx dry

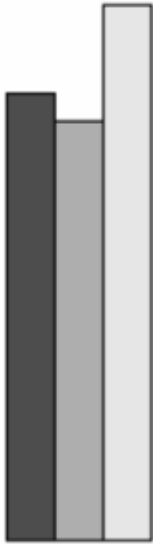

NHx wet

Fig. 3. National dry and wet deposition budgets estimated with FRAME, EMEP and CIEP (wet deposition only) models for year 2008

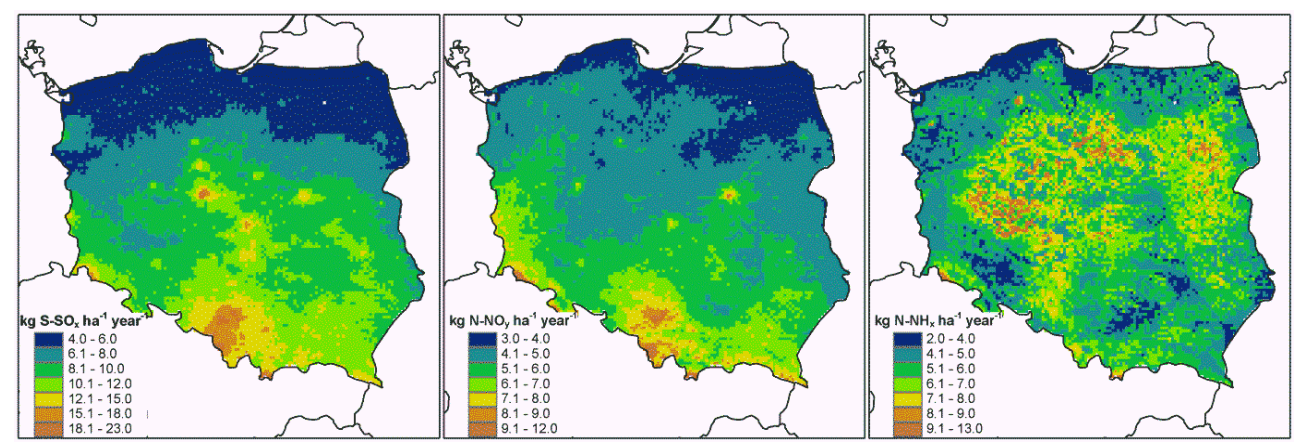

Fig. 4. FRAME modelled total (dry+wet) deposition of sulphur and nitrogen compounds for year 2008

The FRAME modelled deposition of $\mathrm{S}$ is the highest in the large cities and over the industrial areas in Poland (Fig. 4). High deposition values are also calculated over the mountainous regions in the south, for all chemical species considered. Elevated deposition over the mountains is related mainly to the long range transport of atmospheric pollutants, high annual precipitation and the seeder-feeder effect. Deposition of reduced nitrogen $\left(\mathrm{NH}_{\mathrm{x}}\right)$ shows a pattern with highly localized variation if compared with oxidized sulphur and nitrogen, which should be attributed to more scattered emission sources and large dry deposition in the vicinity of the $\mathrm{NH}_{3}$ source areas. The highest values of $\mathrm{NH}_{\mathrm{x}}$ deposition are calculated for central Poland, close to emission sources (intensive agricultural production). 
Country average deposition of oxidized sulphur is $9.4 \mathrm{~kg} \mathrm{~S} \cdot \mathrm{ha}^{-1} \mathrm{y}^{-1}$, and the respective values for oxidized and reduced nitrogen are $6.0 \mathrm{~kg} \mathrm{~N} \cdot \mathrm{ha}^{-1} \mathrm{y}^{-1}$ and $6.5 \mathrm{~kg} \mathrm{~N} \cdot \mathrm{ha}^{-1} \mathrm{y}^{-1}$.

There is close agreement between the FRAME $5 \mathrm{~km}$ x $5 \mathrm{~km}$ and EMEP $50 \mathrm{~km}$ x $50 \mathrm{~km}$ spatial patterns of total sulphur and nitrogen depositions. The grid to grid correlation coefficient is close 0.7 for oxidised $\mathrm{S}$ and N. For reduced nitrogen, grid to grid correlation is 0.54 . The FRAME model gives significantly higher maximum deposition values than EMEP, which can be attributed to the finer spatial resolution. For the oxidised sulphur and nitrogen deposition, FRAME also gives significantly higher $3^{\text {rd }}$ quartile values (11.1 vs $9.0 \mathrm{~kg} \mathrm{~S}-\mathrm{SO}_{\mathrm{x}} \cdot \mathrm{ha}^{-1} \mathrm{y}^{-1}$ and $6.7 \mathrm{vs} 4.8 \mathrm{~kg} \mathrm{~N}-\mathrm{NO}_{\mathrm{y}} \cdot \mathrm{ha}^{-1} \mathrm{y}^{-1}$ ).

Based on the SMB model critical loads of acidity and eutrophication for Polish terrestrial ecosystems were calculated and mapped with the SONOX model [8]. Figure 5 presents the spatial distribution of $C L_{\max } S$ values representing acidification and $C L_{n u t} N$ representing eutrophication. The most sensitive areas to acidification are located in the central and western part of Poland whereas the highest resistance to acidification occurs in the southern and northern regions (Fig. 5). The geographical distribution of $C L_{n u t} N$ is more even across the country with maximum values appearing in the central and eastern part of Poland. The main reason for this spatial pattern is plant available soil water [8].
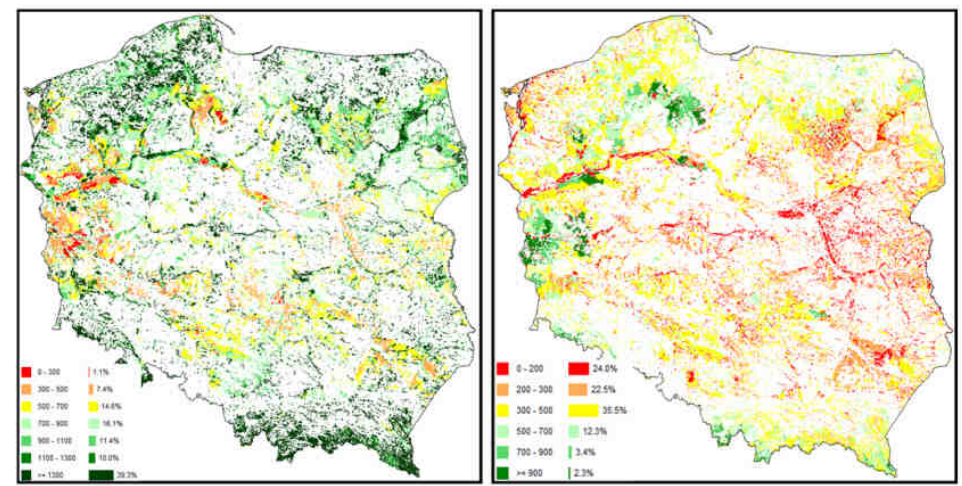

Fig. 5. Critical loads of acidity (left) and eutrophication (right) for Polish terrestrial ecosystems in eq $\mathrm{ha}^{-1} \mathrm{y}^{-1}$

Atmospheric depositions of sulphur and oxidized and reduced forms of nitrogen generated by the FRAME model were combined with the critical loads for acidity and eutrophication. The purpose was to show the magnitude and the geographical extent of the exceedance of critical loads and thus the resultant risk to ecosystems exposed to excess sulphur and nitrogen deposition. Figure 6 shows the spatial distribution of the exceedance of critical loads for acidification and eutrophication derived by use of the 2008 FRAME model $\mathrm{S}$ and $\mathrm{N}$ deposition fields at $5 \mathrm{~km} \times 5 \mathrm{~km}$ grid resolution and the critical loads provided by SONOX.

For the 2008 modelled sulphur and nitrogen depositions nearly $11 \%$ of Polish terrestrial ecosystems were at risk due to the critical load of acidity exceedance. These are both sensitive ecosystems in central Poland and the ecosystems in the emission source areas with relatively high deposition of sulphur and nitrogen. In case of eutrophication, the 
proportion of protected to unprotected ecosystems is almost the reverse. About $95 \%$ of ecosystems area is characterized by the exceedance of critical loads of nutrient nitrogen. The exceedances calculated with the EMEP modelled deposition (50 km x $50 \mathrm{~km} \mathrm{[4])} \mathrm{show}$ that $100 \%$ of the ecosystems suffer from the exceedances of critical loads for eutrophication (data for the year 2010). The differences can be attributed to the spatial distribution of FRAME and EMEP modelled nitrogen deposition. Since 1990 the area unprotected from acidification was reduced by about $65 \%$. In case of eutrophication the reduction of the area under risk is just ca. $2 \%$. This means that a huge effort to further reduce nitrogen emission is needed.
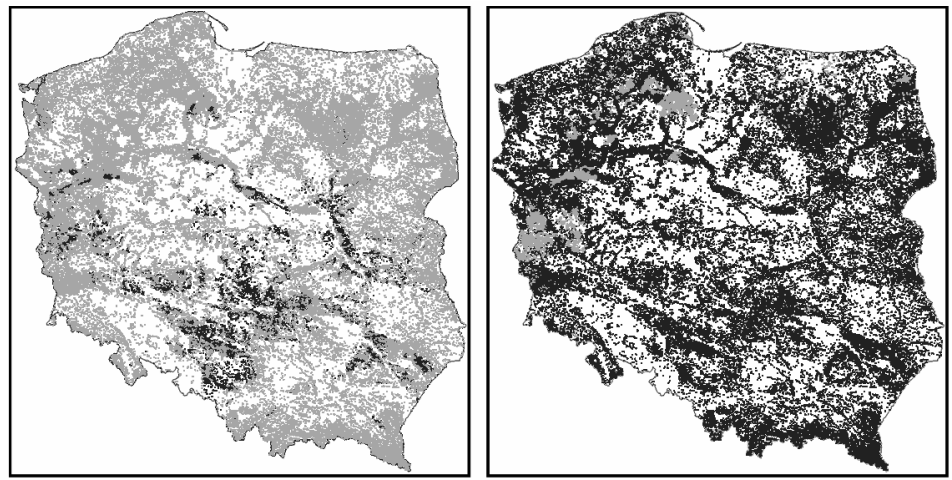

Fig. 6. Exceedance of critical loads of acidity (left) and eutrophication (right). Grey areas - protected ecosystem, black - ecosystems at risk

\section{Discussion and conclusions}

The atmospheric transport model FRAME was used here to provide spatially continuous data on deposition of oxidised sulphur and nitrogen compounds. The results were applied in the SONOX model, which estimates the critical loads for acidity (for sulphur and nitrogen) and eutrophication (for nitrogen compounds only) and their exceedances due to atmospheric deposition. This is the first time that FRAME and SONOX are applied jointly to provide support for environmental management with high spatial resolution.

The FRAME model was found to be in good agreement with wet deposition measurements and the measurement-based national deposition budget provided by CIEP. There is no tendency for under or overestimation of sulphur and nitrogen deposition, with the mean bias close to zero and fraction of two statistic close to one. Therefore the FRAME model results may be applied for assessment of the CL exceedances.

CL exceedances calculated with the SONOX model suggest that the problems related with acidification, as a result of deposition of $\mathrm{S}$ and $\mathrm{N}$ compounds are, to a large extent, now solved in Poland. This is because of the significant abatement of emissions in Poland (eg 80\% of S emission over 1980-2009 period) and entire Europe. At this point the inconsistency between the 35 and $33 \%$ areas at risk of acidity, officially forecasted for the years 2020 and 2030, and the calculated 11\% calculated with SONOX for 2008 is worthy of note. This discrepancy confirms the conclusions derived from the studies reported by Dore 
et al [6] which showed that the area with exceedance generally increased with use of larger grid resolution. The official calculations for Poland were made using the $50 \mathrm{~km}$ x $50 \mathrm{~km}$ spatial resolution of $\mathrm{S}$ and $\mathrm{N}$ depositions against 5-percentile values of critical loads of acidity aggregated to $50 \mathrm{~km}$ grid cells.

On the other hand, extensive areas of Poland are at risk due to large deposition of nitrogen compounds and eutrophication, resulting even with use of the fine $(5 \mathrm{~km} \times 5 \mathrm{~km})$ spatial resolution of this study. This may result in shifts in species composition and a decrease in biodiversity. The results presented here generally agree with the findings of Hettelingh et al [4], though can not be directly compared because of the different spatial patterns of sulphur and nitrogen deposition used in both studies. The support of the general findings presented by Hettelingh et al [4] in terms of exceedances of the critical load for eutrophication by joint application of the FRAME-SONOX models should emphasize the environmental problem of nitrogen deposition for the environment agencies in the area and the importance on introducing regulations to control the emissions of active nitrogen to atmosphere.

\section{Acknowledgements}

The authors are grateful to the Polish National Administration of the Emission Trading Scheme for providing data for this study. This work was supported by the Polish Ministry of Science and Higher Education grant nr N N306 140738.

\section{References}

[1] Mill W. Environ Sci \& Policy. 2006;9:563-567. DOI: 10.1016/j.envsci.2006.05.002.

[2] Bobbink R, Hicks K, Galloway J, Spranger T, Alkemade R, Ashmore M, et al. Ecolog Applicat. 2010;20:30-59. DOI: 10.1890/08-1140.1.

[3] Damgaard C, Jensen L, Frohn LM, Borchsenius F, Nielsen KE, Ejrnaes R, et al. Environ Pollut. 2011;159:1778-1782. DOI: 10.1016/j.envpol.2011.04.003.

[4] Hettelingh J-P, Posch M, Slootweg J. Progress in the modelling of critical thresholds, impacts to plant species diversity and ecosystem services in Europe. CCE Status Report; 2009.

[5] Hallsworth S, Dore AJ, Bealey WI, Dragosits U, Vieno M, Hellsten S, et al. Environ Sci \& Policy. 2010;13:671-687. DOI: 10.1016/j.envsci.2010.09.010.

[6] Dore AJ, Kryza M, Hall JR, Hallsworth S, Keller VJD, Vieno M, et al. Biogeosciences. 2012;9:1597-1609. DOI: $10.5194 /$ bg-9-1597-2012.

[7] Mill W. Environ Protect Eng. 2007;33:39-46.

[8] Mill W, Schlama A. Arch of Environ Protect. 2010;36:117-127.

[9] Fournier N, Dore AJ, Vieno M, Weston KJ, Dragosits U, Sutton MA. Atmos Environ. 2004;38:683-694. DOI: 10.1016/j.atmosenv.2003.10.028.

[10] Dore AJ, Vieno M, Fournier N, Weston KJ, Sutton MA. Quart J Royal Meteorol Soc. 2006;132:2769-2784. DOI: 10.1256/qj.05.198.

[11] Vieno M, Dore AJ, Bealey WJ, Stevenson DS, Sutton MA. Sci Total Environ. 2010;408:985-995. DOI: 10.1016/j.scitotenv.2009.10.048.

[12] Singles R, Sutton MA, Weston KJ. Atmos Environ. 1998;32:393-399. DOI: 10.1016/S1352-2310(97)83467-X.

[13] Kryza M, Werner M, Blas M, Dore AJ, Sobik M. J Air \& Waste Manage Associat. 2010;60:856-866. DOI: 10.3155/1047-3289.60.7.856.

[14] Kryza M, Dore AJ, Blas M, Sobik M. J Environ Manage. 2011;92:1225-1236. DOI: 10.1016/j.jenvman.2010.12.008.

[15] Barret K, Seland O. European Transboundary Acidifying Air Pollution - Ten Years Calculated Field and Budgets to the End of the First Sulphur Protocol. Oslo, Norway: Norweg Meteorolog Instit; 1995. 
[16] Smith RI, Fowler D, Sutton MA, Flechard C, Coyle M. Atmos Environ. 2000;34:3757-3777. DOI: $10.1016 / \mathrm{S} 1352-2310(99) 00517-8$.

[17] Dore AJ, Sobik M, Migala K. Atmos Environ. 1999;33:3301-3312. DOI: 10.1016/S1352-2310(98)00294-5.

[18] Dębski B, Olendrzyński K, Cieślińska J, Kargulewicz I, Skośkiewicz I, Olecka A, Kania K. Inwentaryzacja emisji do powietrza $\mathrm{SO}_{2}, \mathrm{NO}_{2}, \mathrm{CO}, \mathrm{NH}_{3}$, pyłów, metali ciężkich, NMZO, TZO w Polsce za rok 2005. Institute of Environmental Protection; 2009.

[19] Vestreng V, Myhre G, Fagerli H, Reis S, Tarrason L. Atmos Chem and Phys. 2007;7:3663-3681. DOI: 10.5194/acp-7-3663-2007.

[20] Nilsson J, Grennfelt P. Critical loads for sulphur and nitrogen, Report from a workshop held at Skokloster, Sweden, 19-24 March 1988.

[21] Spranger T, Lorenz U, Gregor H-D. Manual on methodologies and criteria for Modelling and Mapping Critical Loads \& Levels and Air Pollution Effects, Risks and Trends. Umweltbundesamt; 2004.

\title{
MODELOWANIE DEPOZYCJI ZWIĄZKÓW SIARKI I AZOTU ORAZ ANALIZA PRZEKROCZEŃ ŁADUNKÓW KRYTYCZNYCH W POLSCE
}

\author{
${ }^{1}$ Zakład Klimatologii i Ochrony Atmosfery, Uniwersytet Wrocławski \\ ${ }^{2}$ Instytut Ochrony Środowiska, KASHUE-KOBIZE, Polska \\ ${ }^{3}$ Centrum Ekologii i Hydrologii, Edynburg, Wielka Brytania
}

\begin{abstract}
Abstrakt: W pracy zastosowano model FRAME do obliczenia informacji o depozycji związków siarki i azotu w Polsce. Na tej podstawie określono przekroczenia ładunków krytycznych dla ekosystemów naturalnych. Po raz pierwszy dwa narzędzia, modele FRAME i SONOX, zostały zastosowane razem w celu określenia zagrożenia dla ekosystemów. Wykazano, że depozycja siarki i azotu, obliczona za pomocą modelu FRAME, jest w dobrej zgodności z dostępnymi pomiarami. Całkowita depozycja siarki, zdeponowanej w Polsce w 2008, została określona na $292 \mathrm{Gg} \mathrm{S}$. Masa zdeponowanych związków azotu (utlenionego i zredukowanego) to $389 \mathrm{Gg} \mathrm{N}$. Wykazano, że $11 \%$ ekosystemów w Polsce jest zagrożonych nadmiernym zakwaszeniem w wyniku depozycji atmosferycznej siarki i azotu, a ponad 95\% ekosystemów lądowych jest zagrożonych eutrofizacją w wyniku depozycji związków azotu.
\end{abstract}

Słowa kluczowe: depozycja siarki, depozycja azotu, ładunki krytyczne, zakwaszenie, eutrofizacja 